\title{
COMPARISION OF INTERNATIONAL CODES FOR STEEL ANCHORS DETAILS USING IN SEISMIC STRENTHENING
}

\author{
${ }^{1}$ Musa Hakan ARSLAN, ${ }^{2}$ Mohamud Abdirahman IBRAHIM \\ ${ }^{1}$ Selcuk University, Department of Civil Engineering, Campus, Selcuklu, Konya, TURKEY \\ ${ }^{2}$ Navitas Professional, 10 Berringa Court, Meadow Heights, Victoria 3048, Melbourne/AUSTRALIA \\ 1mharslan@selcuk.edu.tr, 2tubey@hotmail.com
}

(Geliş/Received: 29.04.2016; Kabul/Accepted in Revised Form: 21.06.2016)

\begin{abstract}
Having poor seismic performance reinforced concrete frame must be strengthened to reach sufficient seismic performance. The main factor that affects the seismic performance, designing and application of the anchor dowels in the connection zone of infill shear wall and weak reinforced frame. Connection between the frame and the infill wall are usually achieved by using dowels that are placed in the holes drilled into inner faces of the frame members, and fixed by a resin. In this study, the design and detailing guidelines for the design of the post-installed anchors in TEC (2007), ACI 318, JCI (2001) and IS15988 have been compared. According to the results, in ACI 318-14, the shear capacity of anchors is effected by embedment depth, anchor bar diameter, concrete strength, strength of the bar and edge distance. In TEC-2007, shear strength is affected only by two properties of the anchor bar: strength and diameter. JCI-2001 design code considers the two factors outlined in TEC-2007 and concrete strength. Based on the comparison conducted in this study, there are insufficient guidelines in TEC-2007 for the design and detailing of anchor bars that are typically used as connection between an existing frame and new RC infill wall.
\end{abstract}

KeyWords: Infill walls, Post-installed anchors, Strengthening, Shear capacity, Detailing.

\section{Sismik Güçlendirmede Kullanılan Ankraj Detayları İçin Uluslararası Yönetmeliklerin Karşılaştırılması}

ÖZ: Deprem performansı yetersiz olan betonarme çerçevelerin yeterli performans seviyesine gelebilmesi için betonarme perde duvarlar ile güçlendirilmesi gerekmektedir. Sonradan yapılan betonarme perde duvarların davranışını etkileyen en önemli unsur çerçeve ve betonarme duvar arasında bağlantı olarak kullanılan ankrajların tasarımı ve uygulamasıdır. Çerçeve ve betonarme dolgu duvarlar arasındaki bağlantı genellikle çerçeve parçalarının iç yüzeylerine açılan deliklere yerleştirilen ankraj donatılarının reçine ile sabitlenmesiyle elde edilir. Bu çalışmada ankrajlar için TEC-2007, ACI 318-14, JCI-2001 ve IS15988 gibi yönetmeliklerde verilen tasarım kuralları karşılaştırılmıştır. Yapılan karşılaştırmaya göre ACI 318-14'te, ankrajların kesme dayanımının gömme derinliği, donatı çapı, beton dayanımı, ankraj donatı dayanımı ve kenar mesafesi ile ilişkili olduğu görülmüştür. TEC-2007'de ise ankrajların kesme dayanımı sadece ankraj donatısının çekme dayanımı ve ankraj çapından etkilendiğinden bahsedilmektedir. ISI5988, JCI-2001'in TEC- 2007' gibi beton basınç dayanımına dikkat ettiği görülmüştür. Bu çalışmada dört yönteminde kıyaslanması sonucunda, mevcut çerçeve ve yeni betonarme dolgu duvar arasında bağlantı olarak kullanılan ankrajlar için TEC-2007'nin yetersiz kaldığı görülmüştür.

Anahtar Kelimeler: Perde duvar, Ankraj, Güçlendirme, Kesme kapasitesi, Detaylandırma

DOI: 10.15317/Scitech.2016320517 


\section{INTRODUCTION}

\section{Background of the Study}

A great number of existing reinforced concrete $(\mathrm{RC})$ buildings require seismic assessment followed by seismic strengthening and repair. One of the most common retrofitting techniques used in seismically active regions, such as Turkey, is the formation of new shear walls by adding cast-in-situ RC walls to some of the bays of the existing frames. The newly added rigid infill walls act primarily as shear walls and relieve the non-ductile existing frames from being subjected to large shear demands. RC infill walls affect both the structural and nonstructural performance of buildings. Many researchers (Phanet al., 1996; Sugano, 1981; Hayashi et al., 1980; Canbay et al., 2002; Sonuvaret al., 2004, Türk et al., 2003) have focused on the addition of infill RC walls and found that RC infill walls which are adequately anchored to the frame members significantly increase the lateral load capacity and stiffness of buildings. Many are focused on tensile behaviour of anchors (Gesoğluet al., 2005; Obata et al.,1998; Sakla and Ashour;2005).

According to the Turkish Seismic Code (TEC-2007), RC infill walls can be formed by either adding concentric shear wall or eccentric infill shear wall. Concentric shear walls refer to infill walls which are arranged within the axis of the existing frame. Typically, the boundary element of the shear wall is formed by using the columns of the existing frame or modifying the columns. Single or coupled shear walls may be connected eccentrically to the exterior frames. Eccentric infill walls are formed by installing $\mathrm{RC}$ walls in parallel or perpendicular to the building's exterior sides, without demolishing any existing partitions or walls. Door or window openings can be provided in RC infill wall for functional reasons, but openings in the walls reduce the stiffness and strength of the wall. Although external shear walls have many advantages, they do not make a positive contribution to the strength of the frame when anchors connecting the external shear walls to the frame are damaged. On the contrary, concentric infill walls, even when designed inadequately or applied incorrectly, tend to have a bracing effect on the frame.

Behavior of RC infill walls under cyclic loading is a very complex phenomenon, for it is a function of many parameters. The response of RC infill walls to an earthquake load depends on geometry and strength of the infill wall, strength and rigidity of the frame elements, amount of infill reinforcement, geometry of openings, etc. Another important parameter that determines the efficiency of the RC infill wall is the interface bond condition between the existing frame and the infill wall. In most common practices, connections such as shear keys, chemical anchors and dowels embedded into the enclosing elements are used to ensure the infill wall is properly connected to the surrounding frame.

\section{Problem Statement}

In the past few decades, it has been recognized by researchers (Sugano, 1981; Ersoy, 1992; Hayashi et al., 1980; Canbayet al., 2003; Sonuvaret al., 2004) and designers that a large percentage of the existing RC buildings in many different countries such as Turkey, Greece, Mexico etc. are inadequate for resisting cyclic lateral loads imposed on them in the event of an earthquake. Many RC structures have either collapsed or experienced different levels of damage during past earthquakes. Investigations revealed that the structural damages were mostly due to repetition of famous errors of the past in the design and construction of RC buildings. Damaged buildings due to earthquake, in general, had irregular structural framing, poor detailing, and insufficient material quality (especially poor concrete compressive strength), poor confinement of reinforcement in connection regions and lack of adequate shear walls. In other words, existing RC buildings exhibit deficiencies due to inadequate design for seismic loads and inadequate seismic design and detailing. Therefore, the knowledge of the behavior of RC infill walls subjected to cyclic loading is critically important for the application of the walls as a seismic retrofitting element for existing RC buildings. 
The effect of RC infill walls on the behavior of RC frames is widely recognized and it has been the subject of numerous studies. However, there are still some parameters which are difficult to quantify and generalize, although they are of primordial significance. These parameters include interface bond condition between the RC infill wall and the existing frame. In most analytical studies, a full and continuous connection between existing frame and the RC infill wall is assumed. Therefore, the effects of the connection properties, such as the diameter, length and arrangement of the dowels, are eliminated. However, the assumption of a full and continuous connection is not always true. Furthermore, the most current design codes and recommendations produced all over the world do not contain guidelines for the design and detailing of RC infill walls, specially the design and detailing of the connection region.

\section{Objectives of the Study}

This study is concerned with the behavior of RC infill walls subjected to cyclic loading. The main objectives of this study can be summarized as follows:

1) Investigate the parameters available in literature on which the strength of the RC infill walls is dependent.

2) To compare the anchorage reinforcement design and detailing rules in some of the current design codes, such as TEC-2007, ACI-314 and other design codes and recommendations.

3) To review parameters affecting the anchorage capacity and understand the behavior of anchorage under static or dynamic loading.

\section{Scope of the Study}

In this study, the design and detailing guidelines for the design of the post-installed anchors in TEC (2007), ACI 318, JCI (2001) and IS15988 have been compared. According to the results, in ACI 318-14, the shear capacity of anchors is effected by embedment depth, anchor bar diameter, concrete strength, strength of the bar and edge distance. In TEC-2007, shear strength is affected only by two properties of the anchor bar: strength and diameter. JCI-2001 design code considers the two factors outlined in TEC2007 and concrete strength. Based on the comparison conducted in this study, there are insufficient guidelines in TEC-2007 for the design and detailing of anchor bars that are typically used as connection between an existing frame and new RC infill wall.

\section{Significance of the Study}

The use RC infill wall is one of the most effective and economic methods for retrofitting/strengthening RC buildings. For the past few decades, the effect of RC infill walls has been the subject of numerous researches ( Canbay, 2001; Ersoy 1992; Anil et al., 2007; Altın et al. 1992; 2008; Erdem et al.,2006 ). However, most of the studies conducted were based on experiments. The behavior of $\mathrm{RC}$ infill walls depends on numerous parameters and there is a high degree of uncertainty associated with those parameters. Due to the above-mentioned factors, current design codes do not contain rules and guidelines for the design of RC infill walls. A systematic presentation of all the information available in literature regarding the effects of all the parameters on the behavior of RC infill walls would contribute to a better understanding of the related phenomena. This can be achieved through a comprehensive literature survey of studies on the use of RC infill walls as strengthening method. Furthermore, the available data in previous researches may also play a role in planning further research work to clarify the role of some significant parameters such as the connection between the wall and the frame. It has been observed that anchoring dowels have a beneficial influence on the behavior of RC infill walls. 
From the available experimental data, the majority of the studies were conducted under the assumption that sufficient anchorage reinforcement had been provided between the new wall and the frame. In addition, several attempts to model analytically the response of RC infill walls to earthquake loading have been presented in literature. In most of these analytical studies, the global behavior of the structure is of the main concern and a full and continuous connection between the wall and the frame is assumed. An analysis with higher accuracy, relatively to the reality condition, is to be established to have better accuracy in structural performance prediction.

\section{MATERIAL AND METHOD}

The effects of RC infill walls on the behavior of RC framed buildings are very important in cases of structures subjected to lateral loading. This chapter contains the literature pertaining to reinforced concrete frames strengthened with reinforced concrete shear walls and their response to lateral loading. This chapter provides an overview of the effects of adding reinforced concrete shear wall to an existing frame and the properties of the wall that affect the behavior of the infilled frame. Typical damage modes resulting from lateral loads on RC infilled are also presented in this chapter. The information was extracted from review of previous researches related to this topic of interest.

Adding a concentric cast-in-place reinforced concrete walls is one of the most common techniques for seismic retrofitting of building structures. RC infill walls can be used to strengthen damaged building and can yield satisfactory results by reducing the seismic damage to the frames and to nonstructural elements. According to Canbay et al. (2003), the new walls are usually introduced by infilling fully or partly strategic bays of the existing frames, especially at the perimeter. If the wall takes up the full width of a bay, it will encapsulate the beams and columns of the frame, and the columns will act as the boundary element of the new wall. That is to say, only the web of the wall is totally new. The new web is fastened to the existing frame using connectors to attach the infill panel to the beams and columns.

The connection with the frame is usually secured by means of appropriate shear connectors made of steel anchors or bonded and/or anchored concrete blocks. Fig.1 shows a typical reinforced concrete frame infilled with concentric reinforced concrete wall. According to Jirsa (1988), the use of E-poxy grouted reinforcing bars and threaded bolts is also a reliable and quick method for providing continuity between the existing and the new reinforced concrete elements. Addition of new RC wall is a viable option for frames which exhibit weaknesses such as soft-storey, inadequate lateral stiffness and undesirable hinging mechanism (Ersoy, 1992). The use of cast in place RC infill walls as a strengthening technique is widespread in Turkey, for it is a reliable method in improving the overall system performance (Canbay et al., 2003). RC infill walls are usually designed and detailed to be critical in flexure, not in shear, and to develop a flexural plastic hinge at the base (Strepelias et al., 2012).

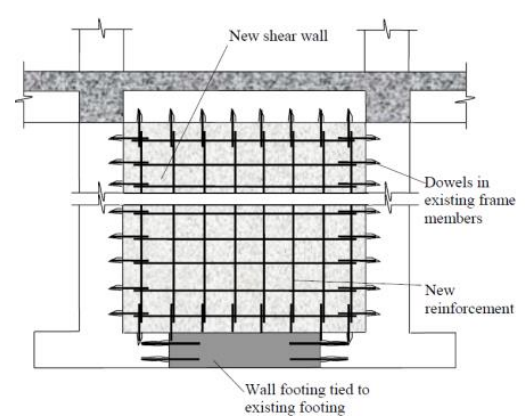

Figure 1.Typical components of an RC frame with RC infill walls (FEMA-440) 


\title{
DESIGN AND DETAILING PROVISIONS FOR ANCHORS
}

\author{
Connection of the Infill Wall to the Frame Members
}

Good anchorage of the new reinforcement to the existing frame is essential for strength, stiffness and deformation capacity (Fardis et al., 2013). Anchorage of the cast-in-place RC wall to the frame is a critical factor in determining overall performance of the structure. Therefore, proper connection has to be provided between the new wall and the existing frame members. Poor detailing and lack of proper loadpath between the old and the new members may lead to global ductility reduction or brittle failure of the infill walls. In common practice, the new walls are connected to existing frames with post-installed anchors.

Post-installed anchors offer more flexibility, and their use is common these days. They are installed in holes that are drilled into the existing RC frame members (i.e. beams and columns). These anchors can be either bonded anchors or mechanical anchors, according to ACI 318-14. The performance of postinstalled bonded anchors depends on the adhesion between the anchor and the adhesive or between the adhesive and the concrete. These anchors can be divided into two main categories: as adhesive and grouted anchors. An adhesive anchor can be either a threaded rod or a deformed reinforcing bar, and is inserted into hardened concrete in a predrilled hole that is typically 10 to 25 percent larger than the diameter of the anchor. These anchors are bonded into the hole using a two part structural adhesive consisting of a resin, e.g. epoxy, and a curing agent to bind the concrete and steel together.

Contrastingly, a grouted anchor can be an unheaded threaded rod, a deformed reinforcing bar, a headed bolt, etc. Grouted anchors are installed into hardened concrete in predrilled holes that are typically 50 to 200 percent larger than the diameter of the anchor. Engineered grouts can be cementitious or polymer based. Cementitious grouts are composed of primarily fine aggregates, Portland cement, and water; polymer grouts are similar in nature to the structural adhesive used to bind adhesive anchors to concrete but also contain a fine aggregate component.

\section{Connection Options}

In many design codes, such as Eurocode 8, guidelines and specific rules for the design of RC frames strengthened with cast-in-place RC walls are not provided. Therefore, a practical approach would be to aim at a composite wall that behaves as fully monolithic wall and designed as such, employing the principles presented in the design codes. In order to achieve a composite wall which complies with the requirements of $R C$ design codes and may be analyzed and verified as a monolithic wall, the reinforcing bars in the new wall should be extended and anchored into the existing frame members past the interface between the new wall and the frame. The traditional approach, as presented in Figure 2-a, is to embed same-diameter starter bars, which are epoxy-grouted into the members of the existing frame and lap-splice them with the web bars on a one-to-one basis. Dowel bars larger but shorter that the starter bars are also provided to transfer shear force. This is a code-conforming method; however it is very expensive and labor-intensive. $1_{\mathrm{o}, \mathrm{d}}$ in Fig.2a is the increased lap length, which is the embedment length of the dowel into the new web.

An indirect method involves the omission of the small-diameter starter bars, as shown in Figure $2 b$. That is to say, the dowels play the role of the starter bars. To this end, each dowel should be extend into the web by at least the lap length of the web bar it is presumed to anchor into the frame member and be dimensioned for simultaneous tension and (dowel) shear (Yilmaz et al.; 2013;2014). To fulfill the requirements specified in the code, the clear distance between the dowel and the reinforcing bar in the web it splices may not exceed the maximum value the code, say Eurocode 2 (BS EN 1992), allows for lapspliced bars. 

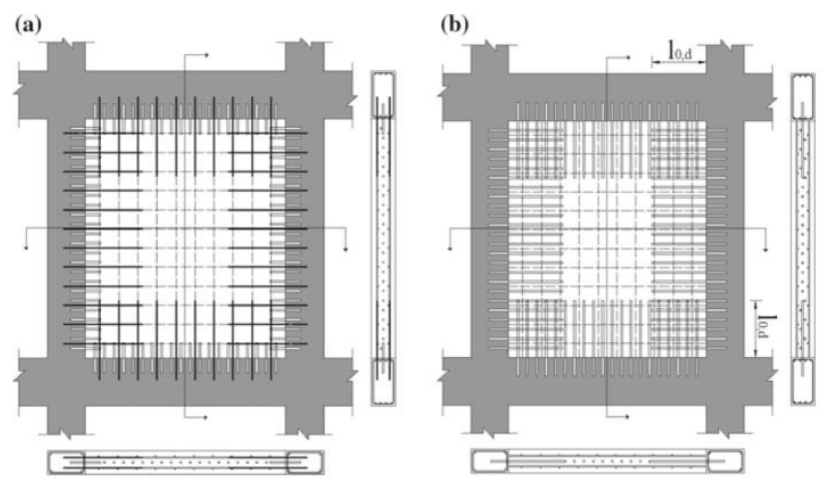

Figure 2.Connection of the new wall to the existing frame members: a) dowels all along the interface, plus starter bars anchored into the frame; b) only dowels all along the interface (Fardiset. al, 2013)

\section{Design and Dimensioning of the Anchor Dowel Bars}

Ensuring safe transfer of earthquake forces between existing frame elements and infill walls is very important. To this end, anchors shall be designed and detailed to transmit the induced forces. A few design codes, such as Japanese and Indian design codes, provide specific guidelines for the design and detailing of the RC frames strengthened with RC walls. However, many design codes, including TEC2007 and ACI 318-14 propose the use of conventional design provisions.

\section{Japanese Code (JCI 2001)}

Design guidelines for the connection between an existing RC frame and a new RC infill wall are presented in the Japanese Code for Seismic Evaluation and Seismic Retrofit of Existing Reinforced Concrete Buildings, 2001. According to this code, the shear capacity $Q_{a}(N)$ is defined as the capacity resisted by a single anchor at the concrete interface. Shear capacity shall be the smaller value of $Q_{a}$ and $\mathrm{Q}_{\mathrm{a} 2}$, which depend on the steel strength and bearing strength of concrete, respectively. It is calculated based on the effective embedment length of an anchor (le).

$$
\mathrm{Q}_{\mathrm{a}}=\min \left[\mathrm{Q}_{\mathrm{a} 1}, \mathrm{Q}_{\mathrm{a} 2}\right]
$$

For bonded anchor in case of $\mathrm{l}_{\mathrm{e}} \geq 7 \mathrm{~d}_{\mathrm{a}}$;

$$
\begin{aligned}
& \mathrm{Q}_{\mathrm{a} 1}=0.7 \sigma_{\mathrm{y}} \mathrm{a}_{\mathrm{e}} \\
& \mathrm{Q}_{\mathrm{a} 2}=0.4 \mathrm{a} \mathrm{e}_{\mathrm{e}} \sqrt{\mathrm{E}_{\mathrm{c}} \sigma_{\mathrm{B}}}
\end{aligned}
$$

But $\tau\left(=\frac{Q_{a}}{a_{e}}\right)$ shall not be greater than $294 \mathrm{~N} / \mathrm{mm}^{2}$.

The tensile capacity $T_{a}(\mathrm{~N})$ is defined as the capacity resisted by a single anchor at the concrete interface. Tensile capacity shall be the smallest value of $\mathrm{T}_{\mathrm{a} 1}$ which is determined by steel strength, $\mathrm{T}_{\mathrm{a} 2}$ which is determined by concrete cone failure, and $\mathrm{T}_{\text {aз }}$ which is determined by bond strength.

$$
\begin{aligned}
& \mathrm{T}_{\mathrm{a}}=\min \left[\mathrm{T}_{\mathrm{a} 1}, \mathrm{~T}_{\mathrm{a} 2}, \mathrm{~T}_{\mathrm{a} 3}\right] \\
& \mathrm{T}_{\mathrm{a} 1}=\sigma_{\mathrm{y}} \mathrm{a}_{0} \\
& \mathrm{~T}_{\mathrm{a} 2}=0.23 \mathrm{~A} \sqrt{\sigma_{\mathrm{B}}} \\
& \mathrm{T}_{\mathrm{a} 3}=\tau_{\mathrm{a}} \pi \mathrm{d}_{\mathrm{a}} \mathrm{l}_{\mathrm{e}} \\
& \tau_{\mathrm{a}}=10 \sqrt{\left(\frac{\sigma_{\mathrm{B}}}{21}\right)}
\end{aligned}
$$

The dimensioning and detailing guidelines and requirements specified in the Japanese code are as follows: 
1. Bonded anchors shall be used to anchor wall reinforcement to develop yielding.

2. The size and arrangement of post-installed anchors shall comply with the following requirements:

a. Diameter of anchor bar da shall be in the range of $13 \mathrm{~mm}$ to $22 \mathrm{~mm}$.

b. Spacing shall not be less than $7.5 \mathrm{da}$, but shall not exceed $300 \mathrm{~mm}$.

c. Transverse center-to-center distance shall not be less than 5.5da for double-layer bar arrangement, and shall not be less than $4 \mathrm{da}$ for staggered arrangement.

d. Distance to wall end shall not be less than 5 da but not greater than spacing.

e. Distance to wall free edge shall not be less than $2.5 \mathrm{da}$. The anchor shall be installed inside concrete cone.

3. Post-installed anchors shall be installed into all beams and columns connected with new wall.

4. Anchorage bars embedded in the new wall shall be deformed steel bars, in general. Their effective anchorage length shall be not less than 20da. The effective embedment length of anchorage bar shall not be less than 7da. Details of post-installed anchors are given in Fig.3.

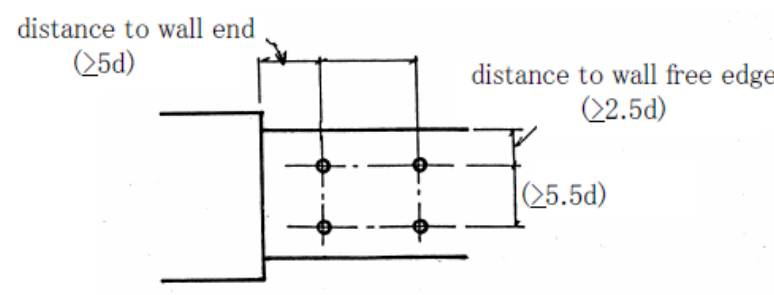

(a) double bar arrangement

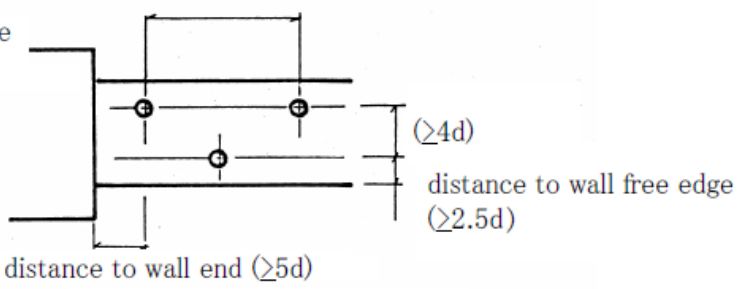

(b) staggered bar arrangement

Figure 3. Details of post-installed anchors

\section{Indian Standard (IS)}

Guidelines for the seismic evaluation and strengthening of existing reinforced concrete buildings guidelines are outlined in the Indian Standard. According to Clause 8.5.2.1 of IS15988, shear transfer reinforcement (dowel bars), perpendicular to the shear plane, is given by:

$$
\operatorname{Avf}=\frac{v_{u}}{\mu f_{y}} \eta
$$

Allowable shear force not greater than $0.2 \mathrm{f}_{\mathrm{ck}} \mathrm{A}_{\text {cst }}$ or $5.5 \mathrm{~A}_{\text {cst }}$ (Acst is the area of concrete section resisting shear transfer); and coefficient of friction is ranged as 1.0 (for concrete placed against hardened concrete with surface intentionally roughened) and 0.75 (for concrete anchored to as-rolled structural steel by headed studs or by reinforcing bars. The efficiency factor is equal 0.5 . Therefore, the number of bars required for resisting shear at the interface can be calculated by using the following equation:

$$
\mathrm{n}=\frac{\mathrm{A}_{\mathrm{vf}}}{\mathrm{A}_{\mathrm{vf}}{ }^{\prime}}
$$

The minimum anchorage length of the longitudinal and transverse reinforcement of the new wall to the existing frame members shall not be less than 6 times the diameter of the bars (Clause 8.5.2.1 (c)). Wherever thickness of column is $250 \mathrm{~mm}$ or less, the new RC wall shall encase the column of the existing frame by wrapping shear wall reinforcement around column after roughening the surface of the column. In case where shear wall spans perpendicular to the larger dimension of column, the transverse 
reinforcement of the RC wall shall be anchored and wrapped around the column surface (Clause 8.5.2.1 (d)).

\section{Turkish Earthquake Code (TEC 2007)}

The design and detailing guidelines for the connection of concentric cast-in-place RC infill wall to the surrounding frame are outlined in clause 7.10.5.1 of the Turkish Earthquake Code, 2007. According to TEC (2007), the new cast-in-place infill walls are arranged within the existing frame axis and made continuous from foundation to their top elevation. Boundary elements are formed either by using or modifying the existing columns of the RC frame. An adequate foundation has to be provided under the added wall.

The integrity of the existing frame and the added concrete infill wall is provided by adequate number of anchor bars detailed according to the Code. The anchors should be designed to resist shear force between the members of the existing frame and the new RC infill wall. The distribution of shear stresses at the interface is recommended to be calculated in accordance with the principles of mechanics. The design should be carried out by using frictional shear stresses guidelines presented in Turkish Building Code (TS-500 (2000)). That is to say, there is no specific formula for calculating the capacity of post-installed bonded anchors in TEC (2007).

The detailing requirements presented in the Turkish Seismic Code are as follows:

1. Anchor bar diameter shall be greater or equal to $16 \mathrm{~mm}$.

2. The embedment depth of the dowels shall not be less than 10 times the diameter of the bar and a maximum spacing of $40 \mathrm{~cm}$ shall be provided.

Formula for calculating the shear capacity of anchors is given in clause 8.1.7 of TS500 and is given in equation (3.11).

$$
V_{r}=\mu A_{w f} f_{y d}
$$

The area of the friction-shear reinforcement is represented as $A_{w f}$ in the equation. The values of the coefficient of friction $(\mu)$ are $0.6,1$ and 1.4 for smooth, rough and monolithic surfaces, respectively. According to the TS 500 (2000) allowable shear force shall be less than $0.2 \mathrm{fcd}_{\mathrm{c}} \mathrm{Ac}_{\mathrm{c}}$.

\section{ACI $318-14$}

General requirements for strength of anchors are outlined in Section 17.3 of ACI318R-14. The capacity of anchor bars is calculated based on failure modes. Three failure modes of anchors subjected to shear force are presented in ACI: Concrete breakout, concrete pry-out for anchors far from a free edge, and steel failure preceded by concrete spall. These failure modes are clearly shown in Fig.4.
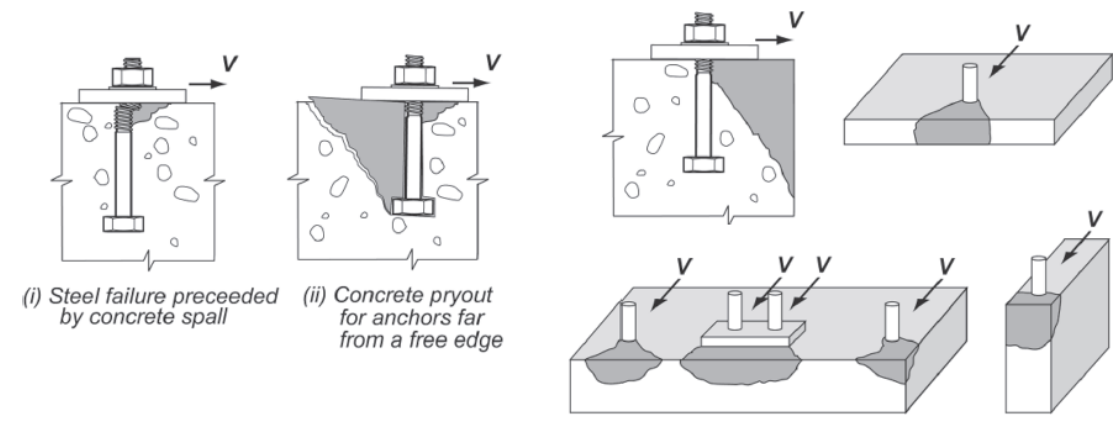

(iii) Concrete breakout

Figure 4.Failure modes of anchors subjected to shear 
The nominal strength of an anchor in shear as governed by steel, $\mathrm{V}_{\mathrm{sa}}$, shall be evaluated by calculations based on the properties of the anchor material and the physical dimensions of the anchor. Where concrete breakout is a potential failure mode, the required steel shear strength shall be consistent with the assumed breakout surface.

a) The nominal strength of an anchor in shear, $\mathrm{V}_{\mathrm{sa}}$, is given in Equation (12).

$$
\mathrm{V}_{\mathrm{sa}}=\mathrm{A}_{\mathrm{se}}, \mathrm{V} \text { futa }
$$

where $\mathrm{Ase}_{\mathrm{se}} \mathrm{V}$ is the effective cross-sectional area of an anchor bar in shear.

b) The nominal concrete breakout strength in shear, $V_{c b}$ of a single anchor or $V_{c b g}$ of a group of anchors, shall not exceed:

i. For shear force perpendicular to the edge on a single anchor:

$$
\mathrm{V}_{\mathrm{cb}}=\frac{\mathrm{A}_{\mathrm{V} c}}{\mathrm{~A}_{\mathrm{V} 0}} \Psi_{\mathrm{ed}}, \mathrm{V} \Psi_{\mathrm{c}}, \mathrm{V} \Psi_{\mathrm{h}}, \mathrm{VV}_{\mathrm{b}}
$$

c) For shear force perpendicular to the edge on a group of anchors:

$$
\mathrm{V}_{\mathrm{cbg}}=\frac{\mathrm{A}_{\mathrm{Vc}}}{\mathrm{A}_{\mathrm{Vc}}} \Psi_{\mathrm{ec}}, \mathrm{V} \Psi \mathrm{ed}, \mathrm{V} \Psi_{\mathrm{c}}, \mathrm{V} \Psi_{\mathrm{h}}, \mathrm{VV} \mathrm{b}
$$

The modification factors $\Psi_{\mathrm{ec}}, \mathrm{V}, \Psi_{\mathrm{ed}}, \mathrm{V}, \Psi_{\mathrm{c}}, \mathrm{V}$, and $\Psi_{\mathrm{h}}, \mathrm{V}$ are defined in Section 17.5 of the code. $\mathrm{V}_{\mathrm{b}}$ is the basic concrete breakout strength value for a single anchor. Avc is the projected area of the failure surface on the side of the concrete member at its edge for a single anchor or a group of anchors. For anchors far from the edge, Eq.12 usually will not govern. For these cases, Eq. 13 and 14 govern.

d) The nominal pryout strength, $V_{c p}$ for a single anchor or $V_{c p g}$ for a group of anchors, shall not exceed:

For a single anchor bar:

$$
\mathrm{V}_{\mathrm{cp}}=\mathrm{k}_{\mathrm{cp}} \mathrm{N}_{\mathrm{cp}}
$$

For a group of anchor bars:

$$
\mathrm{V}_{\mathrm{cpg}}=\mathrm{k}_{\mathrm{cp}} \mathrm{N}_{\mathrm{cpg}}
$$

$\mathrm{N}_{\mathrm{cb}}$ and $\mathrm{N}_{\mathrm{cpg}}$ are the nominal concrete breakout strength in tension of a single anchor, and nominal concrete breakout strength in tension of a group of anchors, respectively. $\mathrm{k}_{\mathrm{cp}}$ is a factor which depends on the effective embedment depth of anchor, hef. (hes $<65 \mathrm{~mm}$ for $\mathrm{k}_{\mathrm{cp}}=1.0$ and $\geq 65 \mathrm{~mm}$ for $\mathrm{k}_{\mathrm{cp}}=2.0$ ). The strength corresponding to the minimum of the values calculated for the three different failure modes is considered. Subsequently, a strength reduction factor for shear loads of 0.65 is multiplied to the design strength. According to ACI 318, the minimum center-to-center spacing of post-installed bonded anchors shall be $6 \mathrm{~d}$.

\section{RESULT AND FINDINGS}

\section{Comparison of the design approaches}

The design provisions of ACI 318-14, TEC-2007, IS15988(2013) and JCI-2001 for post-installed bonded anchors are presented in chapter 3 of this report. There are many differences among the 
provisions in the above mentioned design codes. The main differences include failure modes, load cases and the parameters. These differences are summarized in Table 1.

Table 1.Differences in design provisions

\begin{tabular}{|c|c|c|c|c|}
\hline Design Code & ACI 318-14 & TEC-2007 & JCI-2001 & IS1-5988 \\
\hline Failure Modes & $\begin{array}{l}\text { Tension Failure: } \\
\text { Steel failure } \\
\text { Pullout } \\
\text { Concrete breakout } \\
\text { Concrete splitting } \\
\text { Side-face blowout } \\
\text { Bond failure } \\
\text { Shear Failure: } \\
\text { Steel failure } \\
\text { Concrete pryout } \\
\text { Concrete breakout }\end{array}$ & 更 & $\begin{array}{l}\text { Steel failure } \\
\text { Concrete failure } \\
\text { Bond failure }\end{array}$ & Steel failure \\
\hline Load Cases & Shear and Tension & $\begin{array}{l}\text { Frictional } \\
\text { shear }\end{array}$ & Shear and Tension & Shear \\
\hline Parameters & $\begin{array}{l}\text { Properties of the steel bar and } \\
\text { the concrete and the members. }\end{array}$ & $\begin{array}{l}\text { Strength and } \\
\text { diameter of } \\
\text { the steel }\end{array}$ & $\begin{array}{l}\text { Diameter and strength } \\
\text { of the steel bar, and } \\
\text { properties of the } \\
\text { concrete. }\end{array}$ & $\begin{array}{l}\text { Strength and } \\
\text { diameter of the } \\
\text { steel }\end{array}$ \\
\hline
\end{tabular}

As shown in Table 1, six types of shear failure modes and three types of tension failure modes are considered in ACI 318-14. However, only the failure of steel anchor bar is taken into account in TEC2007 and IS15988(2013). In ACI 318-14, the shear strength of the post-installed anchors depends on the properties of the anchor bar (yield strength, diameter, and embedment depth), edge distance and the compressive strength of concrete. However, only the diameter and yield strength of the anchor bar are required to determine frictional shear in TEC (2007). In general, there are many parameters which arenot considered in TEC (2007) for the design of bonded anchors. Shear capacity of anchor bars is a parameter which all the above-mentioned design codes have in common. The effects of embedment depth, concrete strength, edge distance and diameter of the anchor bars on shear capacity have been determined by carrying out calculations based on TEC-2007 and JCI-2001. However, values for shear capacity accordance with ACI 318-14 are adapted from Çalişkan et al. $(2011 ; 2013)$ for the purpose of comparison.

Figure 5 through Figure 7 show the effects of edge distance on the shear strength of bonded anchors for various concrete strengths in accordance with ACI 318-14, TEC (2007) and JCI(2001). The results are calculated for anchors with diameters of 12,16 and $20 \mathrm{~mm}$ with an embedment depth of $10 \mathrm{~d}$. Shear strength calculated in accordance with TEC (2007) remains constant for anchors with similar diameter, as shown in Figures 5-7. Embedment depth, concrete strength, diameter of the anchor bar, and edge distance have a direct effect on shear capacity in ACI 318-14 design code. On the other hand, shear 
strengths calculated based on JCI (2001) directly depend on the diameter of the anchor bar and concrete strength. According to JCI (2001), as shown in the figures, shear strength remains constant with the change of edge distance, but increases as the diameter of the bar is increased. It is worth noting that, the values obtained using ACI 318-14 are always less than those of TEC (2007), which coincide with the shear strengths of C12 in JCI (2001).

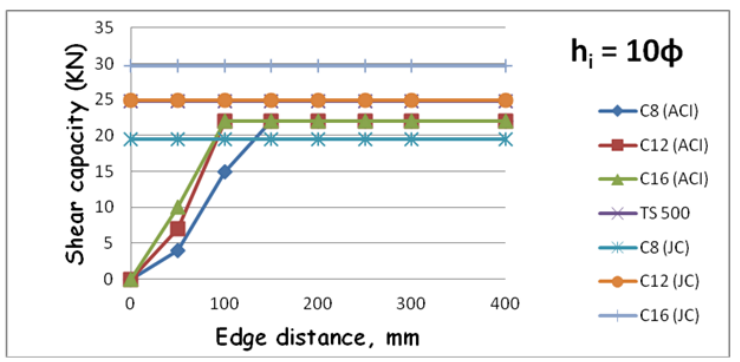

Figure 5. Effect of edge distance on shear capacity for $12 \mathrm{~mm}$ diameter anchors

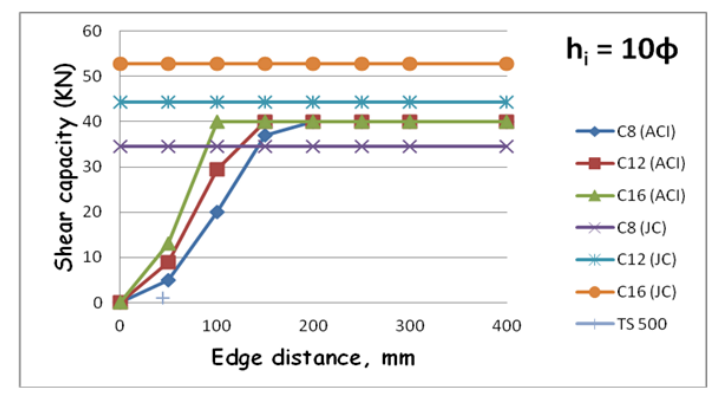

Figure 6.Effect of edge distance on shear capacity for $16 \mathrm{~mm}$ diameter anchors

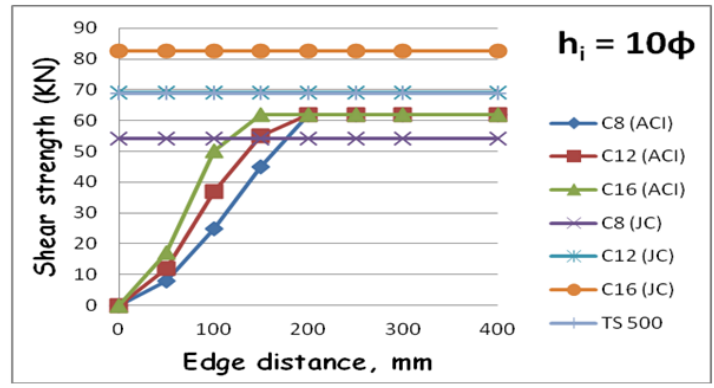

Figure 7.Effect of edge distance on shear capacity for 20mm diameter anchors

Figure 8 through Figure 10 show the effect of concrete strength on shear strength, in accordance with ACI 318-14, JCI-2001 and TEC-2007, of post-installed bonded anchors with varying diameters. In ACI 318-14, at small edge distance, in this case $50 \mathrm{~mm}$, concrete failure determines shear capacity of the anchor irrespective of the concrete strength. However, as the edge distance increases $(100 \mathrm{~mm}$ and $150 \mathrm{~mm}$ ), the shear strength increases to some point (10MPa for $\varphi 12$; $15 \mathrm{MPa}$ for $\varphi 16$ and $20 \mathrm{MPa}$ for $\varphi 20$ ). As for TEC-2007, concrete strength has no effect on the shear strength of the anchors. Increase in 
concrete strength increases the shear capacity specified in JCI (2001); however, the effect ceases to exist for strengths higher than 20MPa.

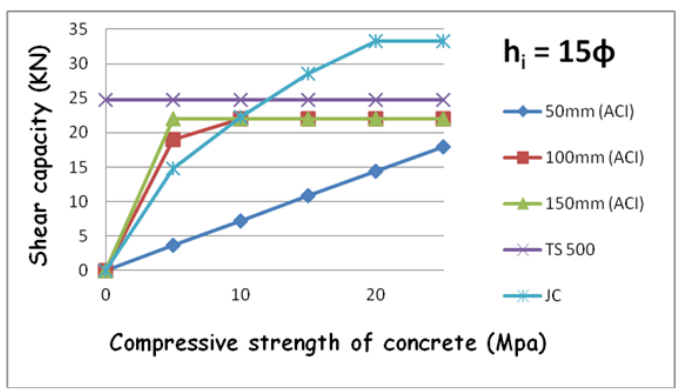

Figure 8.Effect of concrete strength on shear capacity for $12 \mathrm{~mm}$ diameter anchor bars

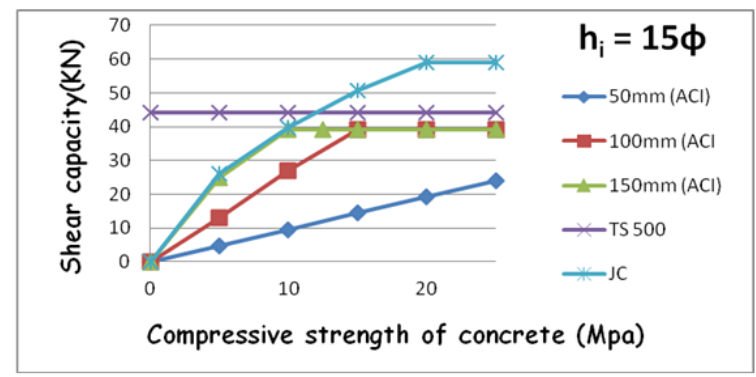

Figure 9.Effect of concrete strength on shear capacity for 16mm diameter anchor bars

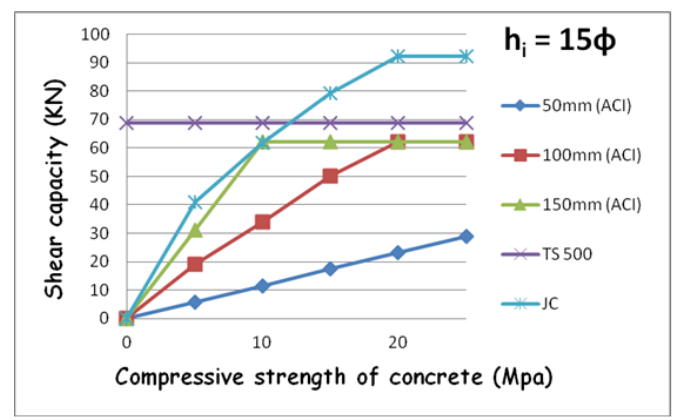

Figure 10.Effect of concrete strength on shear capacity for $20 \mathrm{~mm}$ diameter anchor bars

\section{Comparison of the Detailing Guidelines}

Provisions for the detailing of bonded anchor bars are given in ACI 318-14, TEC-2007, JCI-2001 and IS15988 design codes. These detailing requirements are presented in Table 2. JCI code provides specific detailing requirements for bonded anchors used as a connection between an existing frame and a new RC wall. Minimum diameter and maximum spacing are specified in TEC-2007. However, the factors that are not specified in TEC-2007 include maximum diameter, distance between parallel bars, anchor bar arrangements, and specific anchorage length for bonded anchors.

Besides the detailing guidelines stipulated in the design codes, there are many other detailing requirements proposed by researchers. Phan et al. (1996) proposed a spacing of not less than 7D and not 
greater than $30 \mathrm{~cm}$, where $\mathrm{D}$ is the diameter of the anchor bars. They also proposed an embedment depth of not less than $5 \mathrm{D}$ or the thickness of the concrete cover, whichever is greater.

Table 2.Detailing requirement for bonded anchors

\begin{tabular}{|c|c|c|c|c|}
\hline Detailing Guidelines & JCI-2007 & IS1-5988 & TEC-2007 & ACI 318-04 \\
\hline Diameter, d (mm) & $13 \leq \mathrm{d} \leq 22$ & NG & $\mathrm{d} \geq 16$ & NG \\
\hline Spacing, $\mathrm{S}$ & $\mathrm{S}=7.5 \mathrm{~d} \leq 300 \mathrm{~mm}$ & NG & $\mathrm{S} \leq 400 \mathrm{~mm}$ & $S \geq 6 \mathrm{~d}$ \\
\hline $\begin{array}{l}\text { Clear spacing } \\
\text { b/w parallel bars, } S_{t}\end{array}$ & $\begin{array}{c}S_{t} \geq 5.5 d \text { (double-layer) } \\
\text { St } \geq 4 \mathrm{~d}\end{array}$ & NG & NG & NG \\
\hline Edge Distance, $S_{e}$ & $S_{e} \geq 5 d \leq S$ & NG & NG & $S_{e} \geq 6 \mathrm{~d}$ \\
\hline Anchorage Length, Le & $\mathrm{Le} \geq 10 \mathrm{~d}$ & Le $\geq 6 \mathrm{~d}$ & NG & NG \\
\hline Embedment Depth, $h_{i}$ & $h_{i} \geq 7 d$ & NG & $h_{i} \geq 10 d$ & $4 \mathrm{~d} \leq \mathrm{hi}_{\mathrm{i}} \leq 20 \mathrm{~d}$ \\
\hline
\end{tabular}

$N G=$ Note Given. Wherever acceptable, the conventional design provisions shall be adopted .

\section{RECOMMANDATION AND CONCLUSION}

In this study, previous studies on the behavior of infilled RC frames have been summarized and the design and detailing provisions in ACI 318-14, TEC-2007, IS15988, and JCI-2007 design codes have been investigated and compared. Review of existing experimental data has shown that strengthening RC frames with RC infill walls increases lateral strength and stiffness of the system. In ACI 318-14, the shear strength of the anchor is effected by embedment depth, anchor bar diameter, concrete strength, strength of the bar and edge distance. In TEC-2007, shear strength is affected only by two properties of the anchor bar: strength and diameter. JCI-2007 design code considers the two factors outlined in TEC-2007 and concrete strength. Based on the comparison conducted in this study, there are insufficient guidelines in TEC-2007 for the design and detailing of anchor bars that are typically used as connection between existing frame and new RC infill wall.

There are many variables which could possibly have an effect on the behavior of anchors used to connect new RC wall to existing RC frame; and only a few of them are covered in TEC-2007. Therefore, the effects of those parameters should be studied and incorporated into the code. That is to say, the design and detailing provisions for anchors in TEC-2007 should be revised and specific guidelines should be established.

\section{REFERENCES}

ACI Committee, 2014, Building Code Requirements for Structural Concrete and Commentary (ACI 31814), American Concrete Institute.

Altin, S., Ersoy U., Tankut T., 1992,“'Hysteretic Response of Reinforced-Concrete Infilled Frames”,ASCE Journal of Structural Engineering, Vol.118(8), pp.2133-2150. 
Altin, S., Anil O., Kara E., 2008, "An Experimental Study on Reinforced Concrete Partially Infilled Frames", Engineering Structures, Vol. 29,pp.449-460.

Anil, O., Altin, S., 2007, "An Experimental Study on Reinforced Concrete Partially Infilled Frames", Engineering Structures, Vol. 29, pp.449-460.

Çalışkan, Ö.,Yilmaz, S., and Kaplan, H., 2011, “Güçlendirme Ankrajlarının Kesme Dayanımının ACI318 ve TS500'e Göre Belirlenmesi", Journal of Engineering Sciences, Vol. 14(3), pp. 19-27.

Çalışkan, Ö., Yılmaz S., Kaplan H., Kıraç N., 2013, “Shear Strength of Epoxy Anchors Embedded Into Low Strength Concrete", Construction and Building Materials, Vol. 38, pp. 723-730.

Canbay, E., Ersoy, U.,Ozcebe, G., 2003, “Contribution of Reinforced Concrete Infillsto Seismic Behavior of Structural Systems", ACI Structural Journal, Vol.100(5), pp. 637-643.

Canbay, E., 2001, Contribution of RC Infills to The Seismic Behavior of Structural Systems, PhD Dissertation, Middle East Technical University, Ankara.

Canbay, E., Ersoy U., Özcebe G., 2002, “Betonarme Dolgu Duvarların Yapıların Sismik Davranışı Üzerine Etkileri. Research Report No: INTAG 563", Scientific and Technical Research Council of Turkey-TUBITAK, Ankara.

CEN, EN 1998-3:2005 Eurocode 8: Design of structures for earthquake resistance - Part 3: Assessment and retrofitting of buildings. European Committee of Standardization. Brussels.

Erdem, I., Akyuz, U., Ersoy, U. and Ozcebe, G., 2006, "Experimental and Analytical Studies on The Strengthening of Rc Frames", 13th World Conference on Earthquake Engineering, Vancouver, Canada.

Ersoy, U., 1992, "Repair and Strengthening of RC Structures", International Symposium on Earthquake Disaster Prevention, CENAPRED, Mexico City, pp. 123-138.

Fardis M., Schetakis, A., Strepelias, E., 2013, "RC Buildings Retrofitted by Converting Frame Bays Into RC Walls", Bull Earthquake Eng.,Vol. 11, pp. 1541-1561.

Gesoğlu M., Özturhan T., Özel M., Güneyişi E., 2005, “Tensile Behavior Of Post-Installed Anchors in Plain and Steel Fiber-Reinforced Normal-And High-Strength Concretes", ACI Structural Journal, Vol. 102 (2), pp. 224-231.

Hayashi, T., Niwa, H. and Fukuhara, M., 1980, "The Strengthening Methods of the Existing Reinforced Concrete Buildings", 7th World Conference on Earthquake Engineering, Istanbul, Vol.7, pp.89-96.

IS 15988, 2013, Seismic Evaluation and Strengthening of Existing Reinforced Concrete Buildings Guidelines, New Delhi.

Jirsa, J.O., 1988, “Behaviour of Epoxy-Grouted Dowels and Bolts Used for Repair of Strengthening of RC Structures", Proceedings of 9th World Conference on Earthquake Engineering, Tokyo-Kyoto, pp.371376, 1988.

JCI, 2001, Standard for Seismic Evaluation of Existing Reinforced Concrete Buildings, Japan Building Disaster Prevention Association.

Obata, M., Inoue, M., Goto, Y., 1998, "The Failure Mechanism and The Pull-Out Strength of A BondType Anchor Near A Free Edge",Mechanics of Materials, Vol. 28 (1-4), pp. 113-122.

Sonuvar, M., Ozcebe, G. and Ersoy, U., 2004, "Rehabilitation of Reinforced Concrete Frames with Reinforced Concrete Infills", ACI Structural Journal, Vol. 101 (4), pp. 494-500.

Phan, T., Cheok, S., and Todd, R., 1996, Strengthening Methodology for Lightly Reinforced Concrete Frames: Recommended Design Guidelines for Strengthening with Infill Walls. Gaithersburg: National Institute of Standards and Technology.

Sakla, S.S.S., Ashour, A.F., 2005,"Prediction of Tensile Capacity of Single Adhesive Anchors Using Neural Networks", Computers and Structures, Vol. 83 (21-22), pp. 1792-1803.

Strepelias, E., Palios, X., Bousias, N. and Fardis, N., 2012, "Pseudodynamic Tests on 4-Storey Nonductile Frames with RC Infilling of The Bay", SERIES Workshop: Role of Research Infrastructures in Seismic Rehabilitation, Istanbul, 2012.

Sugano, S., 1981, "Seismic Strengthening of Existing Reinforced Concrete Buildings in Japan", Bulletin of the New Zealand National Society for Earthquake Engineering, Vol. 14(4), pp. 371-378. 
TEC-2007, Ministry of Public Works and Settlement, Turkish Earthquake Code-2007: Specifications For Buildings to Be Built in Seismic Areas, Ankara, Turkey (in Turkish), 2007.

TS500 Betonarme Yapıların Hesap ve Yapım Kuralları, 2000, Türk Standartları Enstitüsü, Ankara.

Turk, M., Ersoy, U., Ozcebe, G., 2003, "Seismic Rehabilitation of RC Frames with RC Infill Walls", Fifth National Conference on Earthquake Engineering, Istanbul-Turkey, pp. 1-9, 2003.

Yilmaz C., Aktas M., Kuyuk S., Yaman D., 2014, “Behavior of RC Frames Strengthened with Infill Panel under Dynamic Loading", Second European Conference on Earthquake Engineering and Seismology, Istanbul-Turkey, pp.861-866, 2014.

Yilmaz S., Özen M.A., Yardim Y., 2013, “Tensile behavior of post-installed chemical anchors embedded to low strength concrete", Construction and Building Materials,Vol. 47, pp. 861-866. 